\title{
Physiologically Relevant Alternative Carbon Sources Modulate Biofilm Formation, Cell Wall Architecture, and the Stress and Antifungal Resistance of Candida glabrata
}

\author{
Shu Yih Chew ${ }^{1}{ }^{1}$, Kok Lian Ho ${ }^{2}$, Yoke Kqueen Cheah ${ }^{3}{ }^{-}$, Doblin Sandai ${ }^{4}$, \\ Alistair J.P. Brown ${ }^{5}$ and Leslie Thian Lung Than ${ }^{1, *}$ \\ 1 Department of Medical Microbiology and Parasitology, Faculty of Medicine and Health Sciences, \\ Universiti Putra Malaysia, Serdang 43400 UPM, Selangor, Malaysia \\ 2 Department of Pathology, Faculty of Medicine and Health Sciences, Universiti Putra Malaysia, \\ Serdang 43400 UPM, Selangor, Malaysia \\ 3 Department of Biomedical Sciences, Faculty of Medicine and Health Sciences, Universiti Putra Malaysia, \\ Serdang 43400 UPM, Selangor, Malaysia \\ 4 Infectomics Cluster, Advanced Medical and Dental Institute, Universiti Sains Malaysia, Kepala Batas 13200, \\ Pulau Pinang, Malaysia \\ 5 MRC Centre for Medical Mycology at the University of Aberdeen, Institute of Medical Sciences, Foresterhill, \\ Aberdeen AB25 2ZD, UK \\ * Correspondence: leslie@upm.edu.my; Tel.: +603-8947-2373
}

Received: 12 April 2019; Accepted: 29 May 2019; Published: 28 June 2019

\begin{abstract}
Flexibility in carbon metabolism is pivotal for the survival and propagation of many human fungal pathogens within host niches. Indeed, flexible carbon assimilation enhances pathogenicity and affects the immunogenicity of Candida albicans. Over the last decade, Candida glabrata has emerged as one of the most common and problematic causes of invasive candidiasis. Despite this, the links between carbon metabolism, fitness, and pathogenicity in C. glabrata are largely unexplored. Therefore, this study has investigated the impact of alternative carbon metabolism on the fitness and pathogenic attributes of C. glabrata. We confirm our previous observation that growth on carbon sources other than glucose, namely acetate, lactate, ethanol, or oleate, attenuates both the planktonic and biofilm growth of $C$. glabrata, but that biofilms are not significantly affected by growth on glycerol. We extend this by showing that $C$. glabrata cells grown on these alternative carbon sources undergo cell wall remodeling, which reduces the thickness of their $\beta$-glucan and chitin inner layer while increasing their outer mannan layer. Furthermore, alternative carbon sources modulated the oxidative stress resistance of $C$. glabrata as well as the resistance of $C$. glabrata to an antifungal drug. In short, key fitness and pathogenic attributes of $C$. glabrata are shown to be dependent on carbon source. This reaffirms the perspective that the nature of the carbon sources available within specific host niches is crucial for C. glabrata pathogenicity during infection.
\end{abstract}

Keywords: Candida glabrata; biofilms; cell wall; antifungal resistance; metabolic adaptation; metabolism; alternative carbon metabolism; pathogenicity

\section{Introduction}

Nutrient assimilation is essential for the growth of all living organisms from microbes to complex multicellular organisms. Without appropriate nutritional resources, pathogens are unable to proliferate and colonise human tissues to establish infections [1]. The diverse microenvironments in the human host are both dynamic and complex in that they often contain mixtures of different carbon sources, 
the concentrations of which change over time [2]. In addition, the host immune system actively deprives invading pathogens of specific nutrients such as essential micronutrients and amino acids [3-6]. Successful human pathogens respond by activating robust nutrient scavenging mechanisms to ensure their survival and propagation within the host [7-10].

Candida species are amongst the most common cause of hospital-acquired systemic mycoses. The spectrum of disease caused by Candida species ranges from superficial infections like oral thrush and vulvovaginal candidiasis (VVC) to lethal invasive infections like invasive candidiasis. Candida albicans is the predominant causative agent of life-threatening systemic candidiasis. Yet there is an alarming increase in the incidence of candidiasis caused by Candida glabrata and other non-C. albicans Candida (NCAC) species [11] due in part to the intrinsic resistance of these species to azole antifungal drugs [12,13].

Candida cells colonising different anatomical sites encounter microenvironments with different carbon source availabilities. Glucose might be an efficient carbon and energy source for the growth of microorganisms in vitro and be present in the bloodstream, but it is scarce in host niches such as the lower gastrointestinal tract or inside macrophages. Indeed, Candida species such as C. albicans and C. glabrata display nutrient starvation responses following phagocytosis by macrophages $[3,7,9,14]$. For this reason, efficient metabolic adaptation is integral to the pathogenicity of Candida species as well as classical virulence factors such as cellular morphogenesis, phenotypic switching, secreted aspartyl proteinases, adhesins, invasins, and biofilm formation $[15,16]$. Genes encoding enzymes involved in gluconeogenesis, the glyoxylate cycle and fatty acid $\beta$-oxidation, are induced following phagocytosis, suggesting that the microenvironment inside macrophages is deficient in glucose and that the engulfed Candida cell must switch to alternative carbon sources. Also, the colon is deficient in glucose, meaning that lactate assimilation is essential for the propagation of $C$. glabrata cells in the gastrointestinal tract [9]. C. glabrata is also able to metabolise acetic acid produced by lactic acid bacteria in the vagina [17].

Adaptation to different carbon sources affects other virulence-related properties. For example, C. albicans cells that metabolise lactate have a thinner cell wall with a reduced $\beta$-glucan and chitin inner layer when compared with glucose-grown control cells [2]. These changes in cell wall architecture in lactate-grown cells enhances the resistance of $C$. albicans to multiple antifungal drugs as well as osmotic and cell wall stresses. Furthermore, $C$. albicans cells exposed to lactate are less visible to innate immune cells than control untreated cells $[18,19]$. Moreover, lactate-grown cells are more efficient in killing the host's macrophages. In contrast, $C$. glabrata cells that assimilate acetate are more susceptible to fluconazole, albeit in the presence of glucose, generate less robust biofilms, and are more susceptible to macrophage killing [20].

Despite the recent increase in the incidence of candidiasis caused by C. glabrata [11,21], relatively little is known about the physiological behaviour of C. glabrata in the host microenvironments. Therefore, in this study we have compared the effects of glucose and alternative carbon utilisation on the growth, biofilm formation, cell wall architecture, stress response, and antifungal susceptibility of C. glabrata.

\section{Results}

\subsection{Alternative Carbon Sources Affect the Planktonic and Biofilm Growth of C. glabrata}

As a starting point, the planktonic growth of $C$. glabrata was compared on glucose and alternative carbon sources using a plate-based microtiter growth assay. C. glabrata grew on all the carbon sources tested in this study, including glucose, acetate, lactate, ethanol, glycerol, and oleic acid (Figure 1a), thereby recapitulating our previous observations [22]. Predictably, the planktonic behaviour of all cultures was similar during the first $4 \mathrm{~h}$ of incubation. On glucose, C. glabrata entered exponential phase after $4 \mathrm{~h}$ whereas, on alternative carbon sources, the $C$. glabrata grown remained in the lag phase for longer (over $6 \mathrm{~h}$ ). Growth was strong on glucose (doubling time, $\mathrm{T}_{\mathrm{d}} \sim 2 \mathrm{~h}$ ) and glycerol $\left(\mathrm{T}_{\mathrm{d}} \sim 6 \mathrm{~h}\right.$ ), medium on lactate $\left(\mathrm{T}_{\mathrm{d}} \sim 8 \mathrm{~h}\right)$, and less strong on oleic acid $\left(\mathrm{T}_{\mathrm{d}} \sim 10 \mathrm{~h}\right)$, ethanol $\left(\mathrm{T}_{\mathrm{d}} \sim 10 \mathrm{~h}\right)$ and acetate $\left(\mathrm{T}_{\mathrm{d}} \sim 14 \mathrm{~h}\right)$. Although C. glabrata utilises a variety of alternative carbon sources, we infer it has a preference for glycerol and lactate over the other alternative carbon sources tested. 
(a)

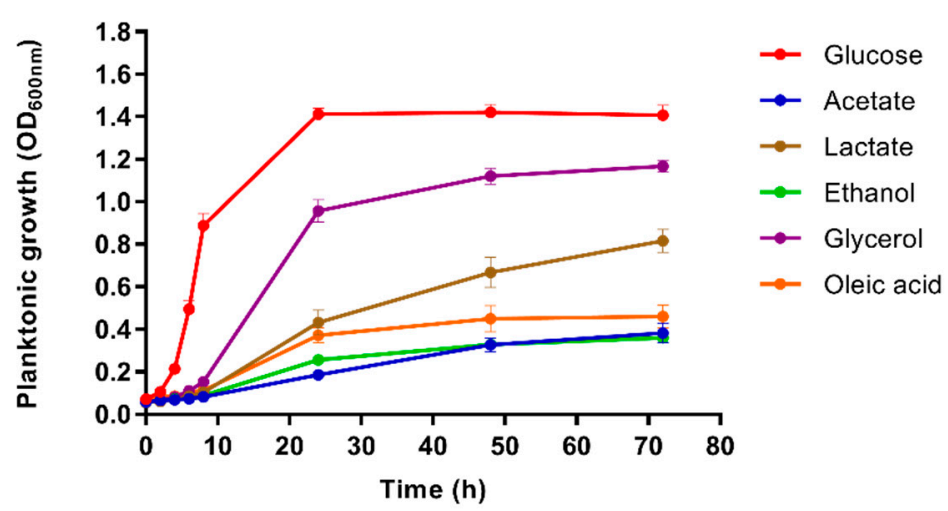

(b)

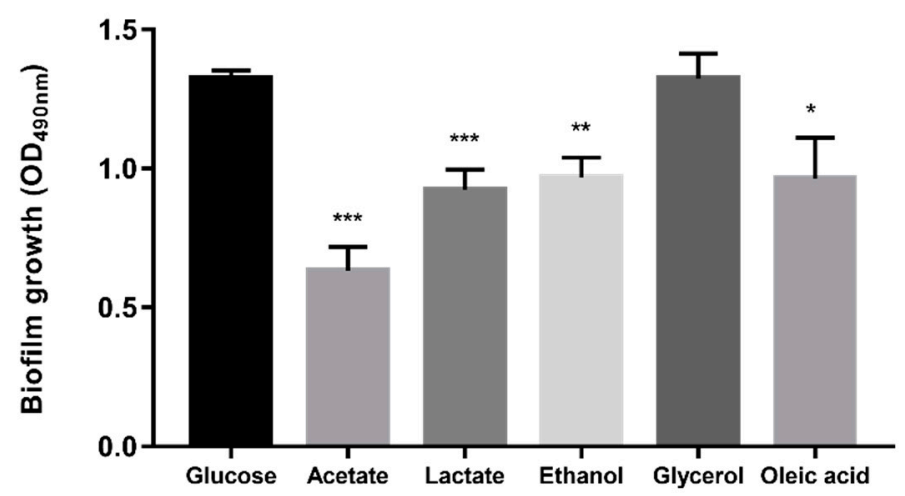

Figure 1. Alternative carbon sources modulate the planktonic and biofilm growth of C. glabrata. (a) Planktonic growth of $C$. glabrata in synthetic complete (SC) media supplemented with $2 \%$ glucose, $2 \%$ acetate, $2 \%$ lactate, $2 \%$ ethanol, $2 \%$ glycerol, or $0.2 \%$ oleic acid and incubated for $72 \mathrm{~h}$ at $37^{\circ} \mathrm{C}$; (b) Biofilm formation of C. glabrata in SC media supplemented with $2 \%$ glucose, $2 \%$ acetate, $2 \%$ lactate, $2 \%$ ethanol, $2 \%$ glycerol, or $0.2 \%$ oleic acid. Results were presented as means \pm SD. ${ }^{*} p<$ $0.05,{ }^{* *} p<0.01$ and ${ }^{* *} p<0.001$ were considered statistically significant relative to the control $(2 \%$ glucose). All experiments were conducted in triplicate, and each independent experiment was repeated three times.

Next, we compared the biofilm growth of C. glabrata on the same carbon sources (Figure 1b). With the exception of glycerol, biofilm growth was reduced significantly on the alternative carbon sources tested when compared with the glucose control. Substantial reductions in biofilm growth were observed for C. glabrata on acetate (52.4\%), lactate (30.3\%), ethanol (26.9\%), and oleic acid $(27.3 \%)$, thereby confirming our previous report [23]. The ultrastructure of these biofilms was examined by SEM (Figure 2). The C. glabrata biofilms comprised only blastoconidia: no filamentous cells were observed. The aggregates of $C$. glabrata cells were smaller in biofilms grown in alternative carbon sources, consistent with the reduced growth on these carbon sources. 

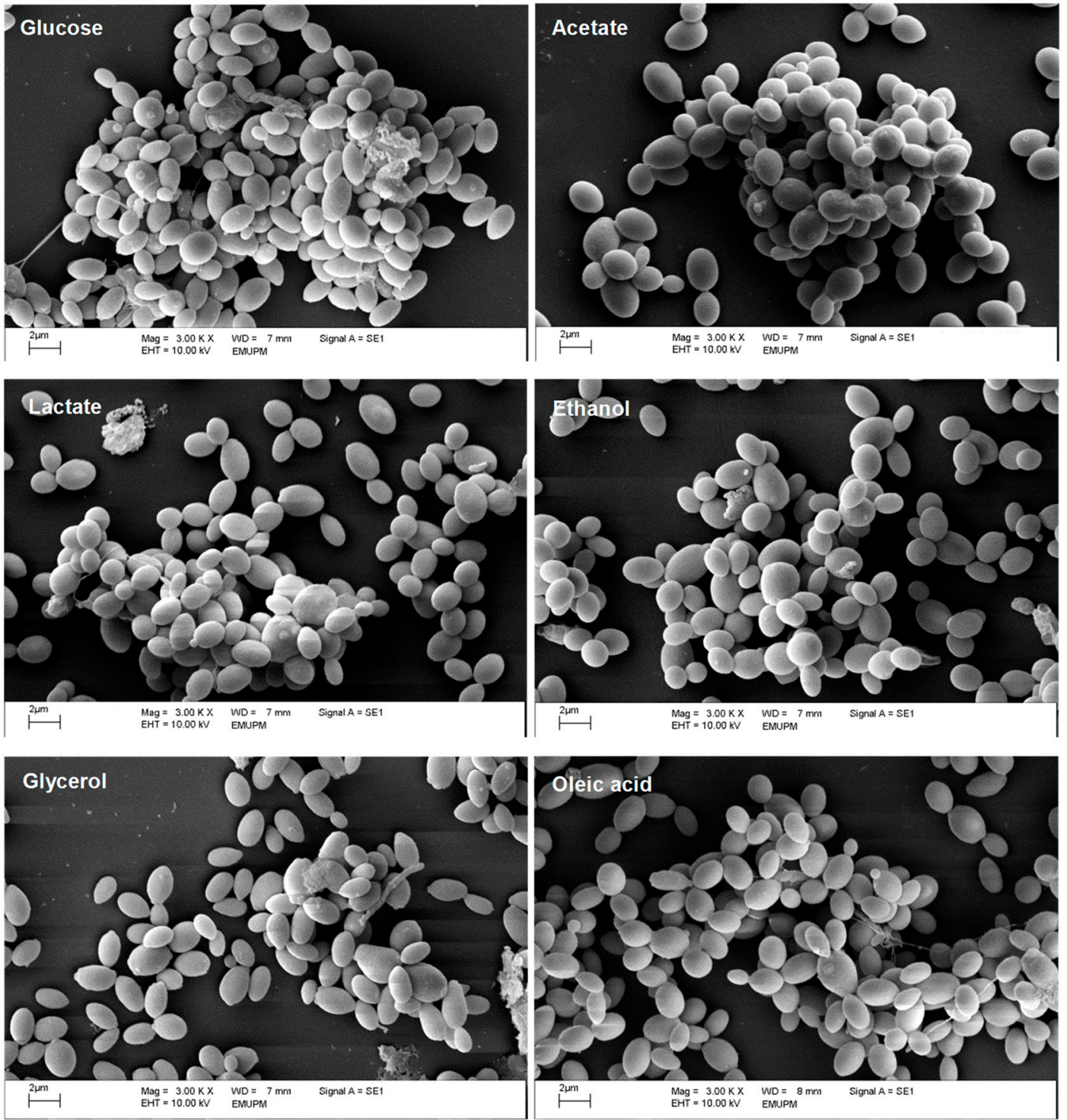

Figure 2. Effect of glucose and alternative carbon sources on the biofilm structures of C. glabrat. Representative scanning electron photomicrographs from $48 \mathrm{~h}$ biofilms of C. glabrata grown on glucose and alternative carbon sources, viewed under scanning electron microscopy (SEM) at a magnification of $3000 \times$. Scale bar represents $2 \mu \mathrm{m}$.

\subsection{Alternative Carbon Sources Influence C. glabrata Cell Wall Architecture}

The effect of alternative carbon sources on the cell wall architecture of $C$. glabrata was investigated by TEM. This revealed significant differences in cell wall architecture and thickness depending on the carbon source (Figure 3a). The thickness of the inner cell wall, which comprises largely $\beta$-glucan and chitin, was reduced significantly following growth on acetate $(57.42 \pm 10.55 \mathrm{~nm})$, lactate $(51.09 \pm 11.80 \mathrm{~nm})$, ethanol $(57.94 \pm 9.48 \mathrm{~nm})$, and oleic acid $(56.72 \pm 7.73 \mathrm{~nm})$ when compared with the glucose control $(81.70 \pm 6.68 \mathrm{~nm})$ (Figure 3b). The effect on the inner cell wall was less dramatic for glycerol $(71.73 \pm 12.40 \mathrm{~nm})$. In contrast, the thickness of the outer mannan layer of the cell wall increased significantly when $C$. glabrata cells were grown on the alternative carbon sources: acetate $(24.58 \pm 3.80 \mathrm{~nm})$, lactate $(31.04 \pm 7.17 \mathrm{~nm})$, glycerol $(25.44 \pm 2.82 \mathrm{~nm})$ and oleic acid $(24.61 \pm 2.78 \mathrm{~nm})$, and glucose control $(20.10 \pm 3.41 \mathrm{~nm})$ (Figure $3 \mathrm{c})$. The increase for ethanol was marginal $(22.93 \pm 2.24 \mathrm{~nm})$. In short, utilisation of some alternative carbon sources led to changes in 
the cell wall architecture of $C$. glabrata, reducing the thickness of $\beta$-glucan and chitin inner layer whilst increasing the thickness of the outer mannan layer.

(a)

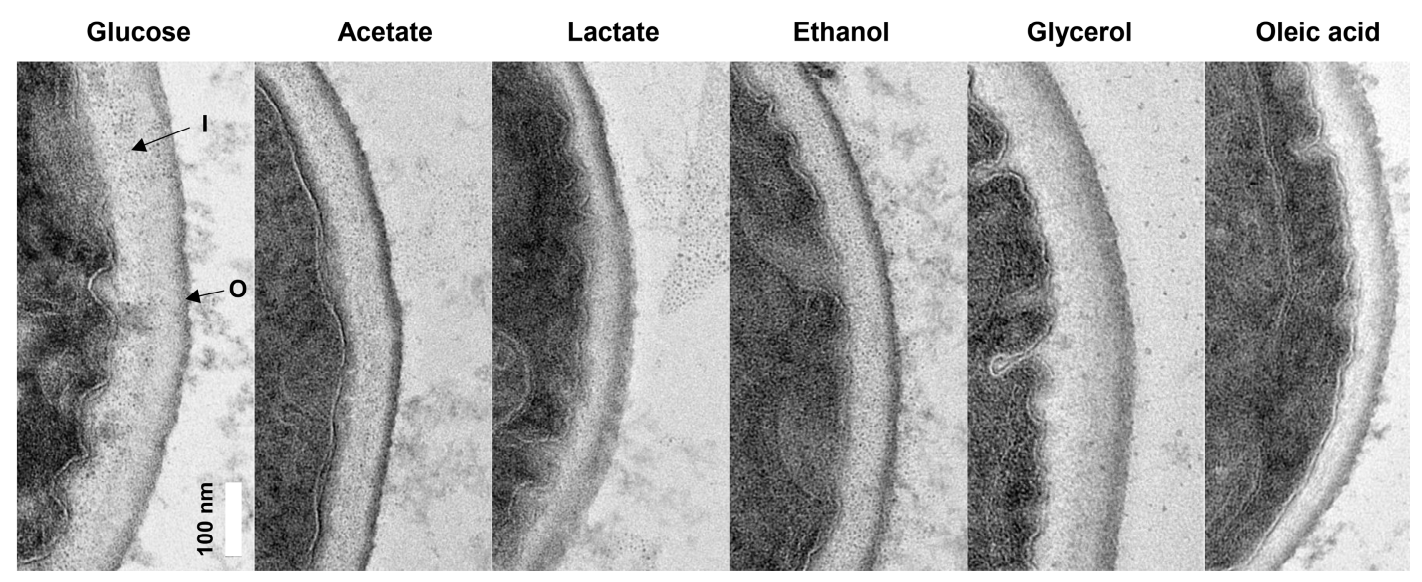

(b)

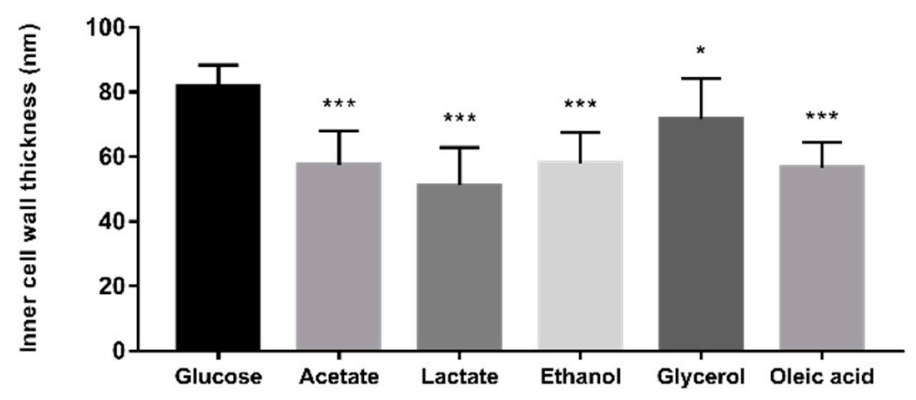

(c)

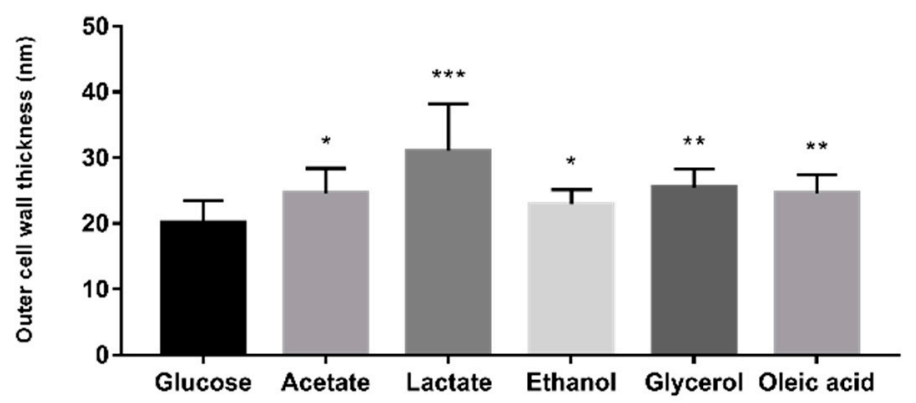

Figure 3. Alternative carbon sources alter the ultrastructure of the C. glabrata cell wall. (a) Representative transmission electron microscopy (TEM) images of cell wall architectures from C. glabrata grown on glucose and alternative carbon sources, [I] indicates inner cell wall layer ( $\beta$-glucan and chitin) and [O] indicates outer cell wall layer (mannan). Scale bar represents $100 \mathrm{~nm}$. (b) Quantification of thickness of the inner cell wall. (c) Quantification of the thickness of the outer cell wall. Results are presented as means \pm SD from 10 individual cells by averaging 20 measurements obtained from the cell periphery of each C. glabrata cells. ${ }^{*} p<0.05,{ }^{* *} p<0.01$ and ${ }^{* * *} p<0.001$ were considered statistically significant relative to glucose-grown cells.

\subsection{Alternative Carbon Sources Reduce the Susceptibility of C. glabrata to Antifungal Drugs}

To investigate the impact of carbon sources on the susceptibility of $C$. glabrata to antifungal drugs, the capacity of $C$. glabrata cells grown on glucose or alternative carbon sources to withstand amphotericin B was examined using a broth microdilution assay. All glucose-grown C. glabrata cells were killed by treatment with $0.5 \mu \mathrm{g} / \mathrm{mL}$ amphotericin B (Figure 4). Significantly, growth on alternative carbon sources reduced the susceptibility of $C$. glabrata cells towards amphotericin B, resisting its fungicidal activity to varying degrees (Figure 4). Lactate- and oleate-grown C. glabrata cells were most resistant to amphotericin B whilst acetate-, ethanol- and glycerol-grown cells were only slightly more 
resistant than the glucose-grown control cells. Our observations suggest that C. glabrata cells growing on alternative carbon sources in vivo may be less sensitive to antifungal therapy.

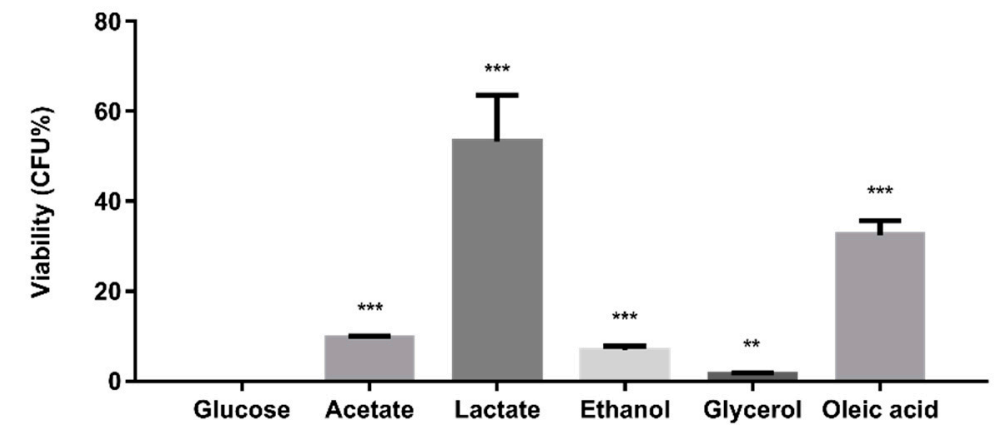

Figure 4. Alternative carbon sources reduce the susceptibility of C. glabrata to amphotericin B. Results are presented as means $\pm \mathrm{SD} .{ }^{* *} p<0.01$ and ${ }^{* * *} p<0.001$ were considered statistically significant relative to glucose-grown cells.

\subsection{Alternative Carbon Sources Modulate the Oxidative Stress Resistance of C. glabrata}

Finally, we investigated the impact of alternative carbon sources on the oxidative stress resistance of $C$. glabrata by examining the sensitivity of this pathogen to hydrogen peroxide $\left(\mathrm{H}_{2} \mathrm{O}_{2}\right)$. As shown in Figure 5, glucose-grown C. glabrata is relatively resistant to high level of $\mathrm{H}_{2} \mathrm{O}_{2}$, which is in agreement with previous findings [23]. However, when C. glabrata was grown on alternative carbon sources, it was much more susceptible to $\mathrm{H}_{2} \mathrm{O}_{2}$ treatment (Figure 5). We conclude that carbon source impacts significantly upon the oxidative stress resistance of C. glabrata.
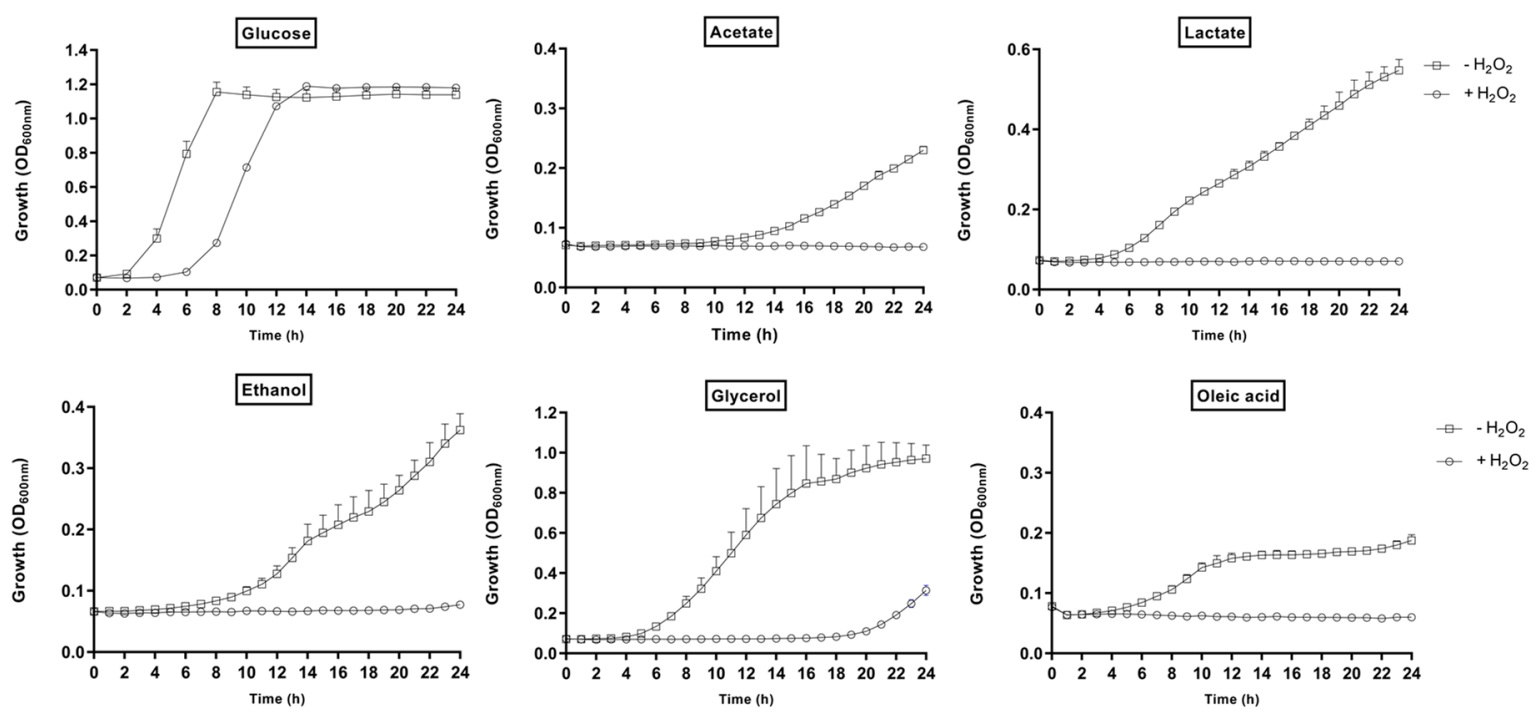

Figure 5. Alternative carbon sources affect the oxidative stress resistance of C. glabrata. Growth of C. glabrata in SC media supplemented with glucose or alternative carbon sources in the presence or absence of $\mathrm{H}_{2} \mathrm{O}_{2}$ was monitored for $24 \mathrm{~h}$ at $37^{\circ} \mathrm{C}$.

\section{Discussion}

Metabolic adaptation is thought to affect the pathogenicity of C. albicans at multiple levels, influencing the expression of virulence factors as well as fitness attributes and also affecting immune surveillance [15]. In C. glabrata, the assimilation of alternative carbon sources is known to be essential for proliferation in glucose-poor niches $[14,22,24]$. However, the impact of alternative carbon sources upon C. glabrata fitness attributes and virulence phenotypes had not been addressed. Therefore, we examined the effects upon biofilm formation, cell wall architecture, and antifungal susceptibility in this study. 
First we confirmed that glucose is the most efficient carbon source for the planktonic growth of C. glabrata of those we tested [22]. Glucose feeds directly into glycolysis, generating intermediates for growth plus energy through a combination of fermentation, the tricarboxylic acid (TCA) cycle, and respiration $[25,26]$. In contrast, growth on glycerol or lactate requires functional gluconeogenesis to generate the hexoses and pentoses required for cell wall and nucleic acid biosynthesis [27]. The assimilation of ethanol or acetate also requires a combination of the glyoxylate and TCA cycles to generate anabolic precursors and energy in addition to gluconeogenesis. Moreover, the utilisation of oleate also requires fatty acid $\beta$-oxidation. In contrast to C. albicans [16,28], $C$. glabrata expresses most of the requisite metabolic enzymes for alternative carbon assimilation only when they are needed [27]. Hence, the diauxic shift from the utilisation of glucose to an alternative carbon source requires time for adaptation, as demonstrated by the longer lag phase during the initiation of $C$. glabrata growth on alternative carbon sources (Figures 1a and 2).

Next, we examined biofilm formation, revealing that C. glabrata forms weaker biofilms on acetate, lactate, ethanol, and oleate when compared with the glucose-grown control (Figure 1b). This observation is in concordance with previous reports showing that $C$. albicans biofilms are greatly reduced during growth on lactate [29] and that C. glabrata biofilms are diminished by the addition of acetate to glucose-containing medium [20]. Interestingly, glycerol does not seem to affect the growth of $C$. glabrata in biofilms. This might relate to the essential regulatory role of glycerol in the expression of biofilm-related functions such as adhesins [30]. Glycerol is required for the synthesis of the glycosylphosphatidylinositol (GPI) anchor, which links adhesins and other mannoproteins to the cell wall and potentially assists in biofilm formation [31].

Several factors, including carbon source, hypoxia, $\mathrm{pH}$, and micronutrient limitation, induce cell wall remodelling in C. albicans [2,32-34]. We show that changes in carbon source also induce changes in cell wall architecture of C. glabrata (Figure 3). Our data indicate that, with the possible exception of glycerol, growth on carbon sources other than glucose is associated with reductions in the thickness of the inner cell wall and, with the possible exception of ethanol, increases in the thickness of outer mannan layer of the cell wall. This differs slightly from the effects of carbon source on the C. albicans cell wall. According to Ene et al. (2012), both the inner and outer layers of the cell wall are thinner for lactate-grown C. albicans cells when compared with their glucose-grown controls [2]. The mechanisms by which carbon sources affect cell wall architecture remain unclear. Nevertheless, these are likely to include direct effects upon the regulation of cell wall biosynthetic genes combined with different rates of provision of essential cell wall precursors via glycolytic versus gluconeogenic metabolism [2]. This could account for the formation of thinner inner cell walls during growth on alternative carbon sources. The extended mannan fibrils in the outer cell wall could conceivably be due to changes in the balance between the extension versus branching of mannan sidechains; environmental signals have been suggested to modulate structure of mannan fibrils $[2,35,36]$. The activation of the cell wall integrity pathway is a common response to environmental challenges in human fungal pathogens [37-41]. Whatever the underlying mechanisms, based on recent findings in C. albicans $[18,19,34]$, the changes in the C. glabrata cell wall that accompany carbon source adaptation are likely to affect the visibility of this pathogen to our innate immune defences.

Changes in carbon source are known to affect the resistance of $C$. albicans to environmental stresses [2,42] and to affect stress signalling mechanisms in this pathogen [43]. C. glabrata displays high levels of intrinsic resistance to such stresses [23], which is related to its evolution as a pathogen that can thrive within the challenging microenvironment of the macrophage [44]. Phylogenetically, C. glabrata is more closely related to S. cerevisiae than C. albicans [45]. In S. cerevisiae, the presence of glucose represses the core stress response via protein kinase A-mediated phosphorylation of the transcription factors Msn2 and Msn4 [46,47]. Candida glabrata has been reported to display a core stress response that resembles that of $S$. cerevisiae [48] and, on this basis, might be expected to be more sensitive to oxidative stress during growth on glucose. However, our data (Figure 5) suggest that $C$. glabrata behaves more like C. albicans, which displays glucose-enhanced oxidative stress resistance [49]. This would be 
consistent with the possibility that, like C. albicans, C. glabrata has evolved an anticipatory response whereby exposure to glucose helps to protect this pathogen against the impending oxidative stress associated with phagocytic assaults $[49,50]$. The effects of carbon source upon the susceptibility of C. glabrata to amphotericin B (Figure 4) are less surprising and are significant in terms of antifungal therapy. Therefore, we argue that carbon source adaptation in C. glabrata is likely to affect the efficacy of clinical treatments as well as fungal pathogenicity.

\section{Materials and Methods}

\subsection{Strain and Growth Condition}

The reference strain C. glabrata ATCC 2001 was used in this study (American Type Culture Collection, Manassas, VA, USA). Standard culture media were used, including YPD (Becton, Dickinson and Company, Franklin Lakes, NJ, USA): yeast extract $(1 \%, w / v)$, peptone $(2 \%, w / v)$, glucose $(2 \%, w / v)$, $\operatorname{agar}(1.5 \%, w / v)$, and yeast nitrogen base (YNB) without amino acids (Becton, Dickinson and Company, USA): yeast nitrogen base $(0.67 \%, w / v)$, ammonium sulfate $(0.5 \%, w / v)$. Synthetic complete (SC) media were prepared with YNB without amino acids, supplemented with complete supplement mixture $(0.2 \%, w / v)$ (Formedium, Hunstanton, UK), glucose $(2 \%, w / v)$, and agar $(2 \%, w / v)$. In addition, glucose was replaced with alternative carbon sources: acetate $(2 \%, w / v)$, lactate $(2 \%, v / v)$, ethanol $(2 \%, v / v)$, glycerol $(2 \%, v / v)$, or oleic acid $(0.2 \%, w / v)$ (Sigma-Aldrich, St. Louis, MO, USA) as the sole carbon source in SC media [2,51].

\subsection{Planktonic Growth Assay}

Growth of C. glabrata in glucose and alternative carbon sources was assessed by plate-based microtiter growth assay [22]. Briefly, C. glabrata was grown in YPD overnight at $37^{\circ} \mathrm{C}$, harvested and washed twice with phosphate-buffered saline (PBS), pH 7.4 before resuspended into fresh SC media supplemented with glucose, acetate, lactate, ethanol, glycerol, and oleic acid as the sole carbon source (OD $600 \mathrm{~nm}$ of 0.1). A volume of $200 \mu \mathrm{L}$ of $C$. glabrata cell suspension was transferred into a sterile 96-well plate and incubated at $37^{\circ} \mathrm{C}$. Growth of $C$. glabrata was monitored for $72 \mathrm{~h}$ by measuring $\mathrm{OD}_{600 \mathrm{~nm}}$ with a microtiter plate reader (Dynex Technologies, Chantilly, VA, USA).

\subsection{Biofilm Formation Assay}

Biofilm formation of $C$. glabrata in glucose and alternative carbon sources was determined by using 2,3-bis-(2-methoxy-4-nitro-5-sulfophenyl)-2H-tetrazolium-5-carboxanilide (XTT) reduction assay as previously described [52]. Overnight culture of $C$. glabrata was harvested, washed twice with PBS, $\mathrm{pH}$ 7.4, and resuspended in SC media supplemented with glucose, acetate, lactate, ethanol, glycerol, and oleic acid as sole carbon source $\left(\mathrm{OD}_{600 \mathrm{~nm}}\right.$ of 0.1$)$. A volume of $100 \mu \mathrm{L}$ of $C$. glabrata cell suspension was dispensed into selected wells of a pre-sterilised, clear and flat bottom 96-well plate. The 96-well plate was covered with its original lid, sealed with parafilm, and incubated for $48 \mathrm{~h}$ at $37^{\circ} \mathrm{C}$. Following $48 \mathrm{~h}$ of incubation, the plate was washed twice with PBS, pH 7.4 to remove the planktonic cells. A volume of $100 \mu \mathrm{L}$ of XTT/menadione solution ( $0.5 \mathrm{~g} / \mathrm{L} \mathrm{XTT,} 10 \mathrm{mM}$ menadione, Sigma-Aldrich, USA) was added to the formed biofilm and incubated in the dark for $3 \mathrm{~h}$ at $37^{\circ} \mathrm{C}$. After $3 \mathrm{~h}$ of incubation, $80 \mu \mathrm{L}$ of the solution was transferred to a new 96-well plate and biofilm formation of C. glabrata was quantified by measuring $\mathrm{OD}_{490 \mathrm{~nm}}$ of the biofilm using a microtiter plate reader.

\subsection{Visualisation of Biofilm Structures}

Biofilm structures of $C$. glabrata grown in glucose and alternative carbon sources were visualised using SEM. Briefly, overnight culture of $C$. glabrata was centrifuged, washed twice with PBS, pH 7.4, and resuspended into fresh SC media supplemented with glucose, acetate, lactate, ethanol, glycerol, and oleic acid $\left(\mathrm{OD}_{600 \mathrm{~nm}}\right.$ of 0.1$)$. Cell suspension was dispensed into a pre-sterilised, clear and flat bottom 6-well polystyrene microtiter plate (Becton, Dickinson and Company, USA) with Nunc Thermanox 
coverslips (Thermo Fisher Scientific, Waltham, MA, USA). The plate was covered with its original lid, sealed with parafilm, and incubated for $48 \mathrm{~h}$ at $37^{\circ} \mathrm{C}$. After $48 \mathrm{~h}$ of incubation, coverslips were fixed in $4 \%(v / v)$ glutaraldehyde (Agar Scientific, Stansted, UK) for $6 \mathrm{~h}$ at $4{ }^{\circ} \mathrm{C}$, followed by washing with $0.1 \mathrm{M}$ sodium cacodylate buffer, pH 7.2 (Agar Scientific, UK) for three times of $10 \mathrm{~min}$ each. Coverslip was post-fixed in $1 \%$ osmium tetroxide $(w / v)$ (Agar Scientific, UK) for $2 \mathrm{~h}$ at $4{ }^{\circ} \mathrm{C}$, washed with $0.1 \mathrm{M}$ sodium cacodylate buffer for three times of $10 \mathrm{~min}$ each, and dehydrated with increasing concentration of acetone (Friendemann Schmidt, Parkwood, Australia): 35\% (v/v) for $10 \mathrm{~min}, 50 \%(v / v)$ for $10 \mathrm{~min}$, $75 \%(v / v)$ for $10 \mathrm{~min}, 95 \%(v / v)$ for $10 \mathrm{~min}$ and $100 \%(v / v)$ for $15 \mathrm{~min}$ (three times). Prior to viewing, coverslips were air-dried in EM CPD030 critical point dryer (Leica, Wetzlar, Germany), mounted onto aluminium stubs and sputter coated with gold using EM SCD050 sputter coater (Leica, Germany). Biofilm structures of $C$. glabrata grown in glucose and alternative carbon sources were observed with LEO 1455 VP SEM (Carl-Zeiss, Oberkochen, Germany).

\subsection{Visualisation of Cell Wall Architecture}

Cell wall architectures of $C$. glabrata grown in glucose and alternative carbon sources were investigated by TEM. Briefly, overnight culture of C. glabrata was centrifuged, washed twice with PBS, pH 7.4, and resuspend in SC media supplemented with glucose, acetate, lactate, ethanol, glycerol, and oleic acid $\left(\mathrm{OD}_{600 \mathrm{~nm}}\right.$ of 0.1$)$. After $48 \mathrm{~h}$ of incubation at $37{ }^{\circ} \mathrm{C}$, cells were fixed in $4 \%(v / v)$ glutaraldehyde for $6 \mathrm{~h}$ at $4{ }^{\circ} \mathrm{C}$. Subsequently, fixative was removed, and horse serum was added to coagulate the cell pellets. After overnight incubation, the coagulated cell pellets were diced into $1 \mathrm{~mm}^{3}$ pieces and fixed in $4 \%(v / v)$ glutaraldehyde for another $2 \mathrm{~h}$ at $4{ }^{\circ} \mathrm{C}$. Following three times of washing with $0.1 \mathrm{M}$ sodium cacodylate buffer, $\mathrm{pH} 7.2$, the samples were post-fixed in $1 \%$ osmium tetroxide $(w / v)$ for $2 \mathrm{~h}$ at $4{ }^{\circ} \mathrm{C}$, washed three times with $0.1 \mathrm{M}$ sodium cacodylate buffer, and dehydrated with increasing concentration of acetone: 35\% (v/v) for $10 \mathrm{~min}, 50 \%(v / v)$ for $10 \mathrm{~min}, 75 \%(v / v)$ for $10 \mathrm{~min}$, $95 \%(v / v)$ for $10 \mathrm{~min}$ and three times of $100 \%(v / v)$ for $15 \mathrm{~min}$. The samples were infiltrated with resin: acetone (1:1) mixture (Agar Scientific, UK) for $1 \mathrm{~h}$, followed by resin: acetone (3:1) mixture for $2 \mathrm{~h}, 100 \%$ resin for overnight and $100 \%$ fresh resin for $2 \mathrm{~h}$. Finally, the samples were embedded in BEEM capsules (Agar Scientific, UK) with $100 \%$ fresh resin and left to polymerisation for $48 \mathrm{~h}$ at $60{ }^{\circ} \mathrm{C}$. Ultrathin sections were cut using EM UC7 ultramicrotome (Leica, Germany) at a thickness of $80 \mathrm{~nm}$. Samples were visualised and imaged with a JEM-2100F field emission electron microscope (JEOL, Tokyo, Japan). Thickness of cell wall layers of $C$. glabrata (chitin plus $\beta$-glucan and mannan) were quantified using Image J by averaging 20 measurements of each cell grown in glucose and alternative carbon sources ( $\mathrm{n}=10$ cells).

\subsection{Antifungal Susceptibility Assay}

Minimum inhibitory concentration (MIC) of amphotericin B against C. glabrata ATCC 2001 was determined by broth microdilution method according to the Clinical and Laboratory Standards Institute (CLSI) M27-A3 document with slight modification by replacing Roswell Park Memorial Institute (RPMI) 1640 medium with SC medium with $2 \%$ glucose. The MIC was confirmed to be $0.5 \mu \mathrm{g} / \mathrm{mL}$. Antifungal susceptibility assay was performed according to the procedure as previously described [53]. Briefly, overnight culture of C. glabrata was resuspended in SC media supplemented with glucose and alternative carbon sources to $\mathrm{OD}_{600 \mathrm{~nm}}$ of 0.1 and regrown to $\mathrm{OD}_{600 \mathrm{~nm}}$ of 0.5 . Cells growing on acetate, lactate, ethanol, and oleic acid were concentrated by centrifugation to achieve this OD. The cell suspensions were treated with $0.5 \mu \mathrm{g} / \mathrm{mL}$ of amphotericin B for $24 \mathrm{~h}$ at $37^{\circ} \mathrm{C}$. Colony-forming-unit (CFU) was determined after incubation and the viability of $C$. glabrata was defined as (CFU of amphotericin B-treated sample / CFU of untreated sample) $\times 100 \%$.

\subsection{Oxidative Stress Assay}

To assess the impact of carbon source on oxidative stress resistance, overnight cultures of $C$. glabrata grown in YPD were harvested and the cells washed twice with phosphate-buffered saline (PBS), pH 7.4, 
before resuspension in fresh SC media supplemented with glucose, acetate, lactate, ethanol, glycerol, or oleic acid as sole carbon source $\left(\mathrm{OD}_{600 \mathrm{~nm}}\right.$ of 0.1$)$. Then $200 \mu \mathrm{L}$ of each C. glabrata cell suspension were transferred into a 96-well microtiter plate and $\mathrm{H}_{2} \mathrm{O}_{2}$ (Sigma-Aldrich, USA) added to a final concentration of 0 or $10 \mathrm{mM}$. Growth was then monitored for $24 \mathrm{~h}$ by measuring $\mathrm{OD}_{600 \mathrm{~nm}}$ with a microtiter plate reader (Thermo Fisher Scientific, USA).

\subsection{Statistical Analyses}

Statistical analyses were performed using GraphPad Prism Version 7.0 Software (GraphPad Software Inc., San Diego, CA, USA). All experiments were performed at least in three replicates and all data were expressed as mean values from all replicates with the corresponding standard deviations (SD). Differences between control and samples were assessed by unpaired t-test and a $p<0.05$ was considered to be statistically significant. All significant differences were indicated in the figures, with *, **, and ${ }^{* * *}$ indicating $p<0.05, p<0.01$ and $p<0.001$, respectively.

\section{Conclusions}

Our data suggest the importance of carbon source adaptation in modulating important fitness and virulence attributes of $C$. glabrata. These include changes in stress resistance and the cell wall. These observations imply that, as C. glabrata cells adapt to the nutrients available within their local microenvironment within the host, this affects the pathogenicity of this fungus and potentially immune responses against the fungus. Furthermore, our data indicate that carbon source adaptation affects susceptibility of this pathogen to antifungal therapy.

Author Contributions: Conceptualization, S.Y.C., D.S., A.J.P.B. and L.T.L.T.; Methodology, S.Y.C., K.L.H., Y.K.C., D.S., A.J.P.B. and L.T.L.T.; Investigation, S.Y.C.; Resources, K.L.H., Y.K.C. and L.T.L.T.; Formal analysis, S.Y.C. and L.T.L.T.; Funding acquisition, L.T.L.T.; Writing—original draft preparation, S.Y.C.; Writing—review and editing, K.L.H., Y.K.C., D.S., A.J.P.B. and L.T.L.T.

Acknowledgments: This study was funded by Fundamental Research Grant Scheme (FRGS) from Ministry of Education (MOE), Malaysia (Grant number: 01-01-14-1456FR). S.Y.C. is a recipient of the MyBrain 15 Scholarship from MOE, Malaysia. AB was supported by the UK Medical Research Council (www.mrc.ac.uk: MR/M026663/1), the Medical Research Council Centre for Medical Mycology (MR/N006364/1), the Wellcome Trust (www.wellcome.ac.uk: 097377), and the European Commission (FunHoMic: H2020-MSCA-ITN-2018-812969).

Conflicts of Interest: The authors declare no conflict of interest.

\section{References}

1. Abu Kwaik, Y.; Bumann, D. Microbial quest for food in vivo: "Nutritional virulence" as an emerging paradigm. Cell Microbiol. 2013, 15, 882-890. [CrossRef]

2. Ene, I.V.; Adya, A.K.; Wehmeier, S.; Brand, A.C.; MacCallum, D.M.; Gow, N.A.; Brown, A.J. Host carbon sources modulate cell wall architecture, drug resistance and virulence in a fungal pathogen. Cell. Microbiol. 2012, 14, 1319-1335. [CrossRef] [PubMed]

3. Lorenz, M.C.; Bender, J.A.; Fink, G.R. Transcriptional response of Candida albicans upon internalization by macrophages. Eukaryot. Cell 2004, 3, 1076-1087. [CrossRef]

4. Hood, M.I.; Skaar, E.P. Nutritional immunity: Transition metals at the pathogen-host interface. Nat. Rev. Microbiol. 2012, 10, 525-537. [CrossRef] [PubMed]

5. Zhang, Y.J.; Rubin, E.J. Feast or famine: The host-pathogen battle over amino acids. Cell Microbiol. 2013, 15, 1079-1087. [CrossRef]

6. Potrykus, J.; Ballou, E.R.; Childers, D.S.; Brown, A.J. Conflicting interests in the pathogen-host tug of war: Fungal micronutrient scavenging versus mammalian nutritional immunity. PLoS Pathog. 2014, 10, e1003910. [CrossRef] [PubMed]

7. Barelle, C.J; Priest, C.L.; Maccallum, D.M.; Gow, N.A.; Odds, F.C.; Brown, A.J. Niche-specific regulation of central metabolic pathways in a fungal pathogen. Cell Microbiol. 2006, 8, 961-967. [CrossRef]

8. Almeida, R.S.; Wilson, D.; Hube, B. Candida albicans iron acquisition within the host. FEMS Yeast Res. 2009, 9, 1000-1012. [CrossRef] 
9. Ueno, K.; Matsumoto, Y.; Uno, J.; Sasamoto, K.; Sekimizu, K.; Kinjo, Y.; Chibana, H. Intestinal resident yeast Candida glabrata requires Cyb2p-mediated lactate assimilation to adapt in mouse intestine. PLoS ONE 2011, 6, e24759. [CrossRef]

10. Citiulo, F.; Jacobsen, I.D.; Miramón, P.; Schild, L.; Brunke, S.; Zipfel, P.; Brock, M.; Hube, B.; Wilson, D. Candida albicans scavenges host zinc via Pra1 during endothelial invasion. PLoS Pathog. 2012, 8, e1002777. [CrossRef]

11. Sardi, J.C.; Scorzoni, L.; Bernardi, T.; Fusco-Almeida, A.M.; Mendes Giannini, M.J. Candida species: Current epidemiology, pathogenicity, biofilm formation, natural antifungal products and new therapeutic options. J. Med. Microbiol. 2013, 62, 10-24. [CrossRef] [PubMed]

12. Arendrup, M.C. Update on antifungal resistance in Aspergillus and Candida. Clin. Microbiol. Infect. 2014, 20, 42-48. [CrossRef] [PubMed]

13. Beardmore, R.E.; Cook, E.; Nilsson, S.; Smith, A.R.; Tillmann, A.; Esquivel, B.D.; Haynes, K.; Gow, N.A.R.; Brown, A.J.P.; White, T.C.; et al. Drug-mediated metabolic tipping between antibiotic resistant states in a mixed-species community. Nat. Ecol. Evol. 2018, 2, 1312-1320. [CrossRef] [PubMed]

14. Kaur, R.; Ma, B.; Cormack, B.P. A family of glycosylphosphatidylinositol-linked aspartyl proteases is required for virulence of Candida glabrata. Proc. Natl. Acad. Sci. USA 2007, 104, 7628-7633. [CrossRef] [PubMed]

15. Brown, A.J.; Brown, G.D.; Netea, M.G.; Gow, N.A. Metabolism impacts upon Candida immunogenicity and pathogenicity at multiple levels. Trends Microbiol. 2014, 22, 614-622. [CrossRef] [PubMed]

16. Childers, D.S.; Raziunaite, I.; Mol Avelar, G.; Mackie, J.; Budge, S.; Stead, D.; Gow, N.A.; Lenardon, M.D.; Ballou, E.R.; MacCallum, D.M.; et al. The rewiring of ubiquitination targets in a pathogenic yeast promotes metabolic flexibility, host colonization and virulence. PLoS Pathog. 2016, 12, e1005566. [CrossRef] [PubMed]

17. Cunha, D.V.; Salazar, S.B.; Lopes, M.M.; Mira, N.P. Mechanistic insights underlying tolerance to acetic acid stress in vaginal Candida glabrata clinical isolates. Front. Microbiol. 2017, 28, 259. [CrossRef]

18. Ene, I.V.; Cheng, S.C.; Netea, M.G.; Brown, A.J. Growth of Candida albicans cells on the physiologically relevant carbon source lactate affects their recognition and phagocytosis by immune cells. Infect. Immun. 2012, 81, 238-248. [CrossRef]

19. Ballou, E.R.; Avelar, G.M.; Childers, D.S.; Mackie, J.; Bain, J.M.; Wagener, J.; Kastora, S.L.; Panea, M.D.; Hardison, S.E.; Walker, L.A.; et al. Lactate signalling regulates fungal $\beta$-glucan masking and immune evasion. Nat. Microbiol. 2016, 12, 16238. [CrossRef]

20. Mota, S.; Alves, R.; Carneiro, C.; Silva, S.; Brown, A.J.; Istel, F.; Kuchler, K.; Sampaio, P.; Casal, M.; Henriques, M.; et al. Candida glabrata susceptibility to antifungals and phagocytosis is modulated by acetate. Front. Microbiol. 2015, 6, 919. [CrossRef]

21. Pfaller, M.A.; Andes, D.R.; Diekema, D.J.; Horn, D.L.; Reboli, A.C.; Rotstein, C.; Franks, B.; Azie, N.E. Epidemiology and outcomes of invasive candidiasis due to non-albicans species of Candida in 2,496 patients: Data from the Prospective Antifungal Therapy (PATH) registry 2004-2008. PLoS ONE 2014, 9, e101510. [CrossRef] [PubMed]

22. Chew, S.Y.; Ho, K.L.; Cheah, Y.K.; Ng, T.S.; Sandai, D.; Brown, A.; Than, L.T.L. Glyoxylate cycle gene ICL1 is essential for the metabolic flexibility and virulence of Candida glabrata. Sci. Rep. 2019, 9, 2843. [CrossRef] [PubMed]

23. Nikolaou, E.; Agrafioti, I.; Stumpf, M.; Quinn, J.; Stansfield, I.; Brown, A.J. Phylogenetic diversity of stress signalling pathways in fungi. BMC Evol. Biol. 2009, 21, 44.

24. Fukuda, Y.; Tsai, H.F.; Myers, T.G.; Bennett, J.E. Transcriptional profiling of Candida glabrata during phagocytosis by neutrophils and in the infected mouse spleen. Infect. Immun. 2013, 81, 1325-1333. [CrossRef] [PubMed]

25. Bertram, G.; Swoboda, R.K.; Gooday, G.W.; Gow, N.A.; Brown, A.J. Structure and regulation of the Candida albicans ADH1 gene encoding an immunogenic alcohol dehydrogenase. Yeast 1996, 12, 115-127. [CrossRef]

26. Askew, C.; Sellam, A.; Epp, E.; Hogues, H.; Mullick, A.; Nantel, A.; Whiteway, M. Transcriptional regulation of carbohydrate metabolism in the human pathogen Candida albicans. PLoS Pathog. 2009, 5, e1000612. [CrossRef]

27. Turcotte, B.; Liang, X.B.; Robert, F.; Soontorngun, N. Transcriptional regulation of nonfermentable carbon utilization in budding yeast. FEMS Yeast Res. 2009, 10, 2-13. [CrossRef]

28. Sandai, D.; Yin, Z.; Selway, L.; Stead, D.; Walker, J.; Leach, M.D.; Bohovych, I.; Ene, I.V.; Kastora, S.; Budge, S.; et al. The evolutionary rewiring of ubiquitination targets has reprogrammed the regulation of carbon assimilation in the pathogenic yeast Candida albicans. MBio 2012, 3, e00495-12. [CrossRef] 
29. Pemmaraju, S.C.; Pruthi, P.A.; Prasad, R.; Pruthi, V. Modulation of Candida albicans biofilm by different carbon sources. Mycopathologia 2016, 181, 341-352. [CrossRef]

30. Desai, J.V.; Bruno, V.M.; Ganguly, S.; Stamper, R.J.; Mitchell, K.F.; Solis, N.; Hill, E.M.; Xu, W.; Filler, S.G.; Andes, D.R.; et al. Regulatory role of glycerol in Candida albicans biofilm formation. mBio 2013, 4, e00637-12. [CrossRef]

31. Orlean, P. Architecture and biosynthesis of the Saccharomyces cerevisiae cell wall. Genetics 2012, 192, 775-818. [CrossRef] [PubMed]

32. Sosinska, G.J.; de Groot, P.W.J.; Teixeira de Mattos, M.J.; Dekker, H.L.; de Koster, C.G.; Hellingwerf, K.J.; Klis, F.M. Hypoxic conditions and iron restriction affect the cell-wall proteome of Candida albicans grown under vagina-simulative conditions. Microbiology 2008, 154, 510-520. [CrossRef] [PubMed]

33. Sherrington, S.L.; Sorsby, E.; Mahtey, N.; Kumwenda, P.; Lenardon, M.D.; Brown, I.; Ballou, E.R.; MacCallum, D.M.; Hall, R.A. Adaptation of Candida albicans to environmental $\mathrm{pH}$ induces cell wall remodelling and enhances innate immune recognition. PLoS Pathog. 2017, 13, e1006403. [CrossRef] [PubMed]

34. Pradhan, A.; Avelar, G.M.; Bain, J.M.; Childers, D.S.; Larcombe, D.E.; Netea, M.G.; Shekhova, E.; Munro, C.A.; Brown, G.D.; Erwig, L.P.; et al. Hypoxia promotes immune evasion by triggering $\beta$-glucan masking on the Candida albicans cell surface via mitochondrial and cAMP-protein kinase A signaling. mBio 2018, 9, e01318. [CrossRef] [PubMed]

35. Kruppa, M.; Greene, R.R.; Noss, I.; Lowman, D.W.; Williams, D.L. Candida albicans increases cell wall mannoprotein, but not mannan, in response to blood, serum and cultivation at physiological temperature. Glycobiology 2011, 21, 1173-1180. [CrossRef] [PubMed]

36. Lowman, D.W.; Ensley, H.E.; Greene, R.R.; Knagge, K.J.; Williams, D.L.; Kruppa, M.D. Mannan structural complexity is decreased when Candida albicans is cultivated in blood or serum at physiological temperature. Carbohydr. Res. 2011, 346, 2752-2759. [CrossRef] [PubMed]

37. Ram, A.F.; Kapteyn, J.C.; Montijn, R.C.; Caro, L.H.; Douwes, J.E.; Baginsky, W.; Mazur, P.; van den Ende, H.; Klis, F.M. Loss of the plasma membrane-bound protein Gas1p in Saccharomyces cerevisiae results in the release of beta 1,3-glucan into the medium and induces a compensation mechanism to ensure cell wall integrity. J. Bacteriol. 1998, 180, 1418-1424. [PubMed]

38. Okawa, Y.; Goto, K. Antigenicity of cell wall mannans of Candida albicans and Candida stellatoidea cultured at high temperatures in BACTEC medium. Biol. Pharm. Bull. 2006, 29, 1723-1727. [CrossRef]

39. Munro, C.A.; Selvaggini, S.; de Bruijn, I.; Walker, L.; Lenardon, M.D.; Gerssen, B.; Milne, S.; Brown, A.J.; Gow, N.A. The PKC, HOG and $\mathrm{Ca}^{2+}$ signalling pathways co-ordinately regulate chitin synthesis in Candida albicans. Mol. Microbiol. 2007, 63, 1399-1413. [CrossRef]

40. Walker, L.A.; Munro, C.A.; de Bruijn, I.; Lenardon, M.D.; McKinnon, A.; Gow, N.A. Stimulation of chitin synthesis rescues Candida albicans from echinocandins. PLoS Pathog. 2008, 4, e1000040. [CrossRef]

41. Lee, K.K.; Maccallum, D.M.; Jacobsen, M.D.; Walker, L.A.; Odds, F.C.; Gow, N.A.; Munro, C.A. Elevated cell wall chitin in Candida albicans confers echinocandin resistance in vivo. Antimicrob. Agents Chemother. 2012, 56, 208-217. [CrossRef] [PubMed]

42. Ene, I.V.; Walker, L.A.; Schiavone, M.; Lee, K.K.; Martin-Yken, H.; Dague, E.; Gow, N.A.; Munro, C.A.; Brown, A.J. Cell wall remodeling enzymes modulate fungal cell wall elasticity and osmotic stress resistance. mBio 2015, 6, e00986. [CrossRef] [PubMed]

43. Kastora, S.L.; Herrero-de-Dios, C.; Avelar, G.M.; Munro, C.A.; Brown, A.J.P. Sfp1 and Rtg3 reciprocally modulate carbon source-conditional stress adaptation in the pathogenic yeast Candida albicans. Mol. Microbiol. 2017, 105, 620-636. [CrossRef] [PubMed]

44. Kasper, L.; Seider, K.; Hube, B. Intracellular survival of Candida glabrata in macrophages: Immune evasion and persistence. FEMS Yeast Res. 2015, 15, fov042. [CrossRef] [PubMed]

45. Shen, X.X.; Zhou, X.; Kominek, J.; Kurtzman, C.P.; Hittinger, C.T.; Rokas, A. Reconstructing the backbone of the Saccharomycotina yeast phylogeny using genome-scale data. G3 2016, 6, 3927-3939. [CrossRef]

46. Gorner, W.; Durchschlag, E.; Martinez-Pastor, M.T.; Estruch, F.; Ammerer, G.; Hamilton, B.; Ruis, H.; Schüller, C. Nuclear localization of the $\mathrm{C}_{2} \mathrm{H}_{2}$ zinc finger protein Msn2p is regulated by stress and protein kinase A activity. Genes Dev. 1998, 12, 586-597. [CrossRef] 
47. Garreau, H.; Hasan, R.N.; Renault, G.; Estruch, F.; Boy-Marcotte, E.; Jacquet, M. Hyperphosphorylation of Msn2p and Msn4p in response to heat shock and the diauxic shift is inhibited by cAMP in Saccharomyces cerevisiae. Microbiology 2000, 146, 2113-2120. [CrossRef]

48. Roetzer, A.; Gregori, C.; Jennings, A.M.; Quintin, J.; Ferrandon, D.; Butler, G.; Kuchler, K.; Ammerer, G.; Schüller, C. Candida glabrata environmental stress response involves Saccharomyces cerevisiae Msn2/4 orthologous transcription factors. Mol. Microbiol. 2008, 69, 603-620. [CrossRef]

49. Rodaki, A.; Bohovych, I.M.; Enjalbert, B.; Young, T.; Odds, F.C.; Gow, N.; Brown, A. Glucose promotes stress resistance in the fungal pathogen Candida albicans. Mol. Biol. Cell 2009, 20, 4845-4855. [CrossRef]

50. Brown, A.; Gow, N.; Warris, A.; Brown, G.D. Memory in fungal pathogens promotes immune evasion, colonisation, and infection. Trends Microbiol. 2019, 27, 219-230. [CrossRef]

51. Sherman, F. Getting started with yeast. Methods Enzymol. 1991, 194, 3-21. [PubMed]

52. Pierce, C.G.; Uppuluri, P.; Tristan, A.R.; Wormley, F.L., Jr.; Mowat, E.; Ramage, G.; Lopez-Ribot, J.L. A simple and reproducible 96-well plate-based method for the formation of fungal biofilms and its application to antifungal susceptibility testing. Nat. Protoc. 2008, 3, 1494-1500. [CrossRef] [PubMed]

53. Ng, T.S.; Desa, M.N.M.; Sandai, D.; Chong, P.P.; Than, L.T.L. Growth, biofilm formation, antifungal susceptibility and oxidative stress resistance of Candida glabrata are affected by different glucose concentrations. Infect. Genet. Evol. 2015, 40, 331-338. [CrossRef] [PubMed]

(C) 2019 by the authors. Licensee MDPI, Basel, Switzerland. This article is an open access article distributed under the terms and conditions of the Creative Commons Attribution (CC BY) license (http://creativecommons.org/licenses/by/4.0/). 